\title{
HUBUNGAN DUKUNGAN KELUARGA DENGAN PEMBERIAN KOLOSTRUM PADA BAYI DI PRAKTIK MANDIRI BIDAN WILAYAH KELURAHAN PAKANSARI KECAMATAN BOGOR TAHUN 2021
}

\author{
Pahlevi $\mathrm{FC}^{1}$, Kusmiran $\mathrm{E}^{2}$, Mulyani $\mathrm{M}^{3}$ \\ ${ }^{I}$ Fungky Pahlevi, Bandung, Indonesia \\ ${ }^{2}$ Eny Kusmiran, Bandung, Indonesia \\ ${ }^{3}$ Irma Mulyani, Bandung, Indonesia
}

\begin{tabular}{l}
\hline ARTICLE INFORMATION \\
\hline Received: October, 14, 2021 \\
Accepted: February, 07, 2022 \\
Available online: February, 08, 2022 \\
KATA KUNCI \\
\hline
\end{tabular}

Dukungan Keluarga, Pemberian Kolostrum CORRESPONDENCE

E-mail: fungky.pahlevi@gmail.com

A B S T R A K

\begin{abstract}
Latar belakang: Kolostrum yang merupakan ASI pertama yang keluar setelah proses kelahiran bayi. Kolostrum memiliki kandungan yang baik untuk bayi, salah satu kandungannya ialah zat kekebalan tubuh yang dapat melindungi bayi dari penyakit. Banyak perdebatan yang terjadi tentang pemberian kolostrum yang beredar di masyarakat. Maka dari itu, dalam tahap menyusui ini ibu menyusui memerlukan peran keluarga untuk mendukung pemberian kolostrum dan meyakinkan bahwa kolostrum baik untuk buah hatinya.

Tujuan Penelitian: Untuk melihat adanya hubungan antara dukungan keluarga dengan pemberian kolostrum pada bayi. Penelitian ini dilakukan di Praktik Mandiri Bidan Wilayah Kelurahan Pakansari Kecamatan Cibinong Kabupaten Bogor tahun 2021.

Metode Penelitian: penelitian ini bersifat survei analitik kuantitatif dengan menggunakan desain pendekatan Cross Sectional dan menggunakan data primer. Populasi dalam penelitian ini adalah ibu bersalin di Praktik Mandiri Bidan wilayah Kelurahan Pakansari Kecamatan Cibinong Kabupaten Bogor yang berjumlah 32 orang, jumlah sampel 32 responden. Pengambilan data dilakukan dengan menggunakan teknik total sampling.

Hasil: Didapatkan persentase tertinggi ialah yang memiliki dukungan tidak baik sebanyak $17(53,1 \%)$ responden, dan yang tidak memberikan kolostrum ada 17 $(53,1 \%)$ responden. Hasil uji chi-square diperoleh $p$-value $<0,001(\alpha<0,05)$.

Simpulan: Terdapat hubungan antara dukungan keluarga dengan pemberian kolostrum pada bayi di Praktik Mandiri Bidan Wilayah Kelurahan Pakansari Kecamatan Cibinong Kabupaten Bogor tahun 2021.
\end{abstract}

dan dilanjutkan dengan pemberian ASI secara terus menerus akan memiliki kekebalan tubuh $10-17$ kali lebih baik.

WHO mengungkapkan bahwa dengan diberikannya

Kolostrum merupakan tahapan pertama kali ASI keluar. Dalam kolostrum yang berwarna agak kekuningan ini mengandung antibodi $10-17$ kali yang lebih banyak dari ASI matur untuk melindungi bayi dari zat yang dapat menimbulkan alergi atau infeksi sebelum memperoleh imunisasi dasar lengkap. Zat kekebalan yang terdapat pada kolostrum dapat melindungi bayi dari penyakit diare dan menurukan kemungkinan bayi terkena penyakit infeksi telinga, batuk, pilek, dan penyakit alergi (Rahmah, 2019). Jika bayi baru lahir tidak diberikan kolostrum maka akan memiliki masalah pada sistem kekebalan tubuh yang dibentuk secara alami. Mengingat kandungan yang terdapat pada kolostrum memiliki zat-zat gizi tinggi dibandingkan dengan ASI matur ataupun susu formula. Bayi yang mendapatkan kolostrum kolostrum pada bayi, dapat menolong $22 \%$ kematian bayi karena pembentukan imunitas yang lebih baik dan pencegahan terhadap serang infeksi yang dapat terjadi pada bayi. Dan data lain dari WHO mengungkapkan ada 170 juta anak mengalami gizi kurang, dan sebanyak 3 juta anak meninggal setiap harinya, kematian ini disebabkan oleh infeksi, saluran pernapasan akut, diare, dan campak, yang sebenarnya dapat dihindari dengan cara memberikan kolostrum pada bayi baru lahir. Selain itu, dengan memberikan ASI mulai dari 1 jam pertama kelahiran hingga berlanjut sampai ASI eksklusif yaitu usia bayi 6 bulan adalah upaya untuk mengurangi statistik gizi kurang di dunia. Sejauh ini, penyumbang angka kematian pada bayi masih didominasi oleh infeksi, tetapi masalah gizi kurang pada anak pun 
menyumbangkan angka kematian yang cukup berarti, sekitar $45 \%$ dari jumlah kematian pada bayi secara keseluruhan (Kementerian Kesehatan RI, 2019).

Didukung oleh rekomendasi yang diberikan oleh World Health Organization (WHO) yang tertulis dalam Rekomendasi IDAI (2010) tentang pemberian ASI adalah menyusui bayi sedini mungkin, sejak 1 jam pertama bayi lahir dilakukan pemberian kolostrum, lalu berlanjut hingga 6 bulan pertama untuk pencapaian ASI eksklusif, dan berlanjut hingga usia 2 tahun atau lebih. Ikatan Dokter Anak Indonesia (IDAI) tahun 2010 juga mengatakan, ASI selain sebagai sumber nutrisi juga dapat memberikan perlindungan kepada bayi melalui berbagai komponen zat kekebalan yang dikandungnya. Komponen ASI lain yang juga memiliki efek perlindungan, antara lain sitokin, laktoferin, lisozim dan musin. Tidak ada satupun susu formula yang memiliki kandungan sebaik ASI yang memiliki zat untuk daya tahan tubuh anak.

Peran kolostrum amatlah sangat besar sebagai pemberian ASI pertama pada bayi baru lahir, yaitu untuk pertumbuhan dan perkembangan bayi. Namun, masih sering terjadi kesalahpahaman mengenai ASI pertama atau kolostrum untuk diberikan kepada bayi baru lahir. Banyak keluarga beranggapan, bahwa ASI yang diproduksi pertama kali ialah susu basi yang tidak layak dikonsumsi bayi dan dapat mengakibatkan bayi terserang diare atau penyakit lainnya. Pada nyatanya kolostrum mengandung $\operatorname{IgA}$ dengan kadar sampai $5000 \mathrm{mg} / \mathrm{dL}$ yang cukup untuk melapisi permukaan saluran cerna bayi terhadap bakteri pathogen dan virus (Zakiudin dan Nia, 2013).

Dari data yang diperoleh pada laman Pusat Data dan Informasi Kementerian Kesehatan RI mengenai Menyusui Sebagai Dasar Kehidupan (2018), di Indonesia persentase bayi baru lahir yang dilakukan IMD sebanyak 73,06 \% pada tahun 2017 sedangkan target yang tertulis untuk IMD ialah $80 \%$. Indonesia berada diurutan ke-9 negara dengan kasus gizi kurang. Di Indonesia dari setiap 1.000 kelahiran 40 diantaranya akan meninggal sebelum mereka berusia 5 tahun, 1/3 kematian bayi di Indonesia terjadi pada bulan pertama setelah kelahiran, $80 \%$ diantaranya terjadi pada minggu pertama kelahiran, penyebab pertama kematian adalah diare, infeksi pernafasan, dan komplikasi kelahiran Menurut UNICEF (2018), hampir 3 dari 10 anak berusia di bawah lima tahun menderita stunting atau terlalu pendek, sedangkan 1 dari 10 kekurangan berat badan atau terlalu kurus untuk usia mereka. Seperlima anak usia dasar kelebihan berat badan atau obesitas.

Di Jawa Barat dari data yang diperoleh pada laman Pusat Data dan Informasi Kementerian Kesehatan RI mengenai Menyusui Sebagai Dasar Kehidupan (2018), terdapat sebanyak $75,88 \%$ bayi baru lahir yang dilakukan IMD. Data kematian pada neonatus di Jawa Barat yang diperoleh dari Profil Anak Indonesia (2018) ada sebanyak 15 per 1.000 kelahiran hidurp. Disebutkan bahwa angka tersebut mengalami penurunan dari tahun sebelumnya. Sedangkan persentase bayi baru lahir di Kabupaten Bogor yang dilakukan IMD terdata sebesar 22,42\% (Dinkes Kab. Bogor, 2015). Angka Kematian Neonatus di Kabupaten Bogor tercatat sebanyak 169 kasus kematian, diantaranya disebabkan karena infeksi, diare, dan campak. Dari data yang diperoleh, pemerintah terus melakukan upaya promosi mengenai pentingnya IMD pada bayi baru lahir, agar ibu, keluarga dan tenaga kesehatan khususnya bidan dapat melakukannya dengan kerjasama yang baik guna mencapai cakupan yang telah ditentukan oleh pemerintah dengan harapan dapat menaikan angka harapan hidup dan juga penurunan angka kematian balita akibat infeksi.

Berdasarkan hasil penelitian yang dilakukan oleh Ikrawanty Ayu dan Basuki Rahmat (2017) didapatkan data bahwa ada $22(25.3 \%)$ ibu nifas dan menyusui yang tidak memberikan kolostrum yang diakibatkan oleh pengetahuan yang kurang serta tidak dapatnya dukungan dari kelurga. Presentase ibu nifas dan menyusui yang tidak memndapatkan dukungan keluarga sebanyak 12 orang $(57.1 \%)$. Hal tersebut menunjukan bahwa dukungan keluarga memiliki peran tinggi dalam pemberian kolostrum. Sedangkan, data yang didapatkan dari penelitian yang dilakukan oleh Dewi Andriani (2017), ada 25 ibu nifas dan menyusui (59.5\%) yang tidak memberikan kolostrum. Banyak faktor yang menyebabkannya, diantaranya karena pengetahuan, sikap, dan dukungan keluarga. Pada penelitian tersebut masih didapatkan data sebanyak $20 \mathrm{ibu}$ nifas dan menyusui $(47.6 \%)$ yang tidak mendapatkan dukungan keluarga untuk memberikan kolostrum.

Selain itu, penelitian yang dilakukan oleh Maryani, Sunarti Dode dan Syafaraenan (2018) didapatkan hasil terdapat hubungan antara pengetahuan, dukungan keluarga, dan sumber informasi dengan pemberian kolostrum pada bayi baru lahir di RSUD Labuangbaji Makassar. Pada variable pengetahuan didapatkan hasil sebanyak 9 responden (30\%) yang memberikan kolostrum, 6 responden (20\%) diantaranya yang memiliki pengetahuan yang cukup dan 3 responden $(10 \%)$ yang memiliki pengetahuan kurang. Sedangkan variable dukungan keluarga memiliki jumlah responden sebanyak $23,30 \%$ yang mendapatkan dukungan baik dari keluarga untuk memberikan kolostrum, dan $53,30 \%$ responden yang tidak memberikan kolostrum karena tidak mendapatkan dukungan keluarga. Dan variable sumber informasi menunjukan sebesar 30\% responden mengetahui dengan baik informasi mengenai kolostrum dan memberikannya kepada bayi mereka, dan ada $50 \%$ responden yang tidak mengetahui dengan baik mengenai kolostrum sehingga mereka tidak memberikannya.

\section{METODE}

Penelitian ini merupakan penelitian survei analitik kuantitatif dengan menggunakan desain pendekatan Cross Sectional. Teknik pengambilan sampel menggunakan total sampling. Sampel dalam penelitian ini ialah ibu nifas 1-3 hari yang melahirkan normal di Praktik Mandiri Bidan wilayah Kelurahan Pakansari Kecamatan Cibinong Kabupaten Bogor sebanyak 32 responden. Pengumpulan data menggunakan kuesioner. Analisis data yaitu analisis univariat dan analisis bivariat untuk melihat distribusi frekuensi serta mengetahui apakah dukungan keluarga mempengaruhi pemberian kolostrum (Notoatmodjo, 2015). 


\section{HASIL DAN PEMBAHASAN}

\section{HASIL}

Tabel 4.2 Distribusi Frekuensi Dukungan Keluarga Pada Ibu Menyusui Untuk Memberikan Kolostrum Pada Bayi Di Praktik Mandiri Bidan Wilayah Kelurahan Pakansari Kecamatan Cibinong Kabupaten Bogor Tahun 2021

\begin{tabular}{lcc}
\hline \multicolumn{1}{c}{ Dukungan Keluarga } & N & \% \\
\hline Tidak Mendukung & 17 & 53,1 \\
Mendukung & 15 & 46,9 \\
\hline Total & $\mathbf{3 2}$ & $\mathbf{1 0 0 , 0}$ \\
\hline
\end{tabular}

Berdasarkan Tabel 4.2 menunjukan dari total sampel sebanyak 32 responden yang bersalin terdapat sebagian besar responden memiliki dukungan keluarga yang tidak baik terhadap ibu menyusui di Praktik Mandiri Bidan Wilayah Kelurahan Pakansari Kecamatan Cibinong Kabupaten Bogor Tahun 2021 dengan jumlah 17 responden $(53,1 \%)$.

Tabel 4.3 Distribusi Frekuensi Pemberian Kolostrum Pada Bayi Di Praktik Mandiri Bidan Wilayah Kelurahan Pakansari Kecamatan Cibinong Kabupaten Bogor Tahun 2021

\begin{tabular}{lcc}
\hline Pemberian Kolostrum & N & \% \\
\hline Tidak Diberikan & 17 & 53,1 \\
Diberikan & 15 & 46,9 \\
\hline Total & $\mathbf{3 2}$ & $\mathbf{1 0 0 , 0}$ \\
\hline
\end{tabular}

Berdasarkan Tabel 4.3 dari total sampel sebanyak 32 responden terdapat $17(53,1 \%)$ responden yang tidak memberikan kolostrum pada bayi di Praktik Mandiri Bidan Wilayah Kelurahan Pakansari Kecamatan Cibinong Kabupaten Bogor Tahun 2021. Yang artinya, sebagian besar responden ibu menyusui tidak memberikan kolostrum kepada bayinya.

Tabel 4.4 Hubungan Dukungan Keluarga Dengan Pemberian Kolostrum Pada Bayi Di Praktik Mandiri Bidan Wilayah Kelurahan Pakansari Kecamatan Cibinong Kabupaten Bogor Tahun 2021

\begin{tabular}{|c|c|c|c|c|c|c|c|}
\hline \multirow{3}{*}{$\begin{array}{c}\text { Dukungan } \\
\text { Keluarga }\end{array}$} & \multicolumn{6}{|c|}{ Pemberian Kolostrum } & \multirow{3}{*}{$\begin{array}{c}p- \\
\text { valu } \\
e\end{array}$} \\
\hline & \multicolumn{2}{|c|}{$\begin{array}{c}\text { Tidak } \\
\text { Diberikan }\end{array}$} & \multicolumn{2}{|c|}{ Diberikan } & \multicolumn{2}{|c|}{ Jumlah } & \\
\hline & $\mathbf{n}$ & $\%$ & $\mathbf{N}$ & $\%$ & $\mathbf{n}$ & $\%$ & \\
\hline $\begin{array}{c}\text { Tidak } \\
\text { Mendukung }\end{array}$ & 17 & 100 & 0 & 0,0 & 17 & 100 & \\
\hline Mendukung & 0 & 0,0 & 15 & 100 & 15 & 100 & 01 \\
\hline Total & 17 & 53,1 & 15 & 46,9 & 32 & 100 & \\
\hline
\end{tabular}

Berdasarkan Tabel 4.4 penelitian yang dilakukan di Praktik Mandiri Bidan Wilayah Kelurahan Pakansari Kecamatan
Cibinong Kabupaten Bogor Tahun 2021 didapatkan p-value $<0,001$.

\section{PEMBAHASAN}

\section{Dukungan Keluarga}

Berdasarkan penelitian yang dilakukan mengenai dukungan keluarga dengan pemberian kolostrum pada bayi di Praktik Mandiri Bidan Wilayah Kelurahan Pakansari Kecamatan Cibinong Kabupaten Bogor pada tahun 2021, hasil penelitian menunjukan bahwa sebagian besar ibu menyusui yang melahirkan normal di Praktik Mandiri Bidan Wilayah Kelurahan Pakansari Kecamatan Cibinong Kabupaten Bogor tidak didukung dalam memberikan kolostrum kepada bayinya, yaitu sebesar $(53,1 \%)$. Dari penelitian yang dilakukan, dilihat dari beberapa aspek dukungan keluarga didapatkan data bahwa dukungan keluarga dari aspek dukungan penilaian dan dukungan emosional memiliki nilai yang cenderung rendah kepada ibu nifas dan menyusui. Sedangkan dukungan informasi memiliki nilai yang sedikit lebih baik dari aspek dukungan lainnya.

Dukungan keluarga adalah sikap, tindakan dan penerimaan keluarga terhadap penderita yang sakit. Sedangkan menurut Fatmawati (2013) anggota keluarga memandang bahwa orang yang bersifat mendukung selalu siap memberikan pertolongan dan bantuan jika diperlukan.

Hal tesebut sesuai dengan penelitian yang dilakukan oleh Neni Ekowati Januariana dan Marnaini Malaila (2021) menunjukan ada 16 (64\%) responden yang memiliki dukungan tidak baik, yang mana menunjukan respon terhadap responden untuk tidak memberikan kolostrum kepada bayinya. Dari penelitian yang dilakukan oleh Neni Ekowati Januariana dan Marnaini Malaila (2021) maka dapat dilihat bahwa penelitian yang dilakukan sejalan.

Hal yang serupa juga ditemukan pada penelitian Purwaningsih, Hasanah dan Utomo (2013) yang menyatakan bahwa dukungan keluarga akan membentuk keseimbangan mental dan kepuasan psikologis ibu pekerja. Pemberian dukungan keluarga juga dapat memberikan keberhasilan dalam pekerjaan ibu. Keluarga yang memberikan dukungan keluarga seperti dukungan emosi, instrumental, penghargaan maupun informasi akan meningkatkan motivasi ibu dalam menikmati semua peran ganda yang dimilikinya.

Pada penelitian yang dilakukan oleh Liva Maita dan Na'imatu Shalihah (2015), didapatkan hasil serupa. Bahwa dukungan keluarga merupakan faktor penting dalam pemberian kolostrum, dinyatakan dengan $p$-value $\leq 0,05$. Di mana peran keluarga dapat menciptakan suasana yang hangat dan menyenangkan. Dalam hal ini, dukungan keluarga merupakan keterlibatan anggota keluarga dalam turut andil merawat bayi dan memberikan informasi kepada ibu mengenai ASI. Dari hasil tersebut, ibu yang mendapatkan informasi dari keluarga mengenai ASI terdorong untuk memberikan kolostrum pada bayinya.

Berdasarkan teori yang dikemukakan oleh Ayuni (2020), dukungan keluarga adalah sikap, tindakan dan penerimaan keluarga terhadap penderita yang sakit . Anggota keluarga memandang bahwa orang yang bersifat mendukung selalu siap memberikan pertolongan dan bantuan jika diperlukan. Sehingga, dukungan keluarga amat sangat berperan dalam keberhasilan sesuatu, termasuk pemberian kolostrum pada bayi. Dukungan keluarga merupakan faktor eksternal yang paling besar pengaruhnya terhadap keberhasilan ASI eksklusif (Roesli, 2008). 


\section{Pemberian Kolostrum}

Berdasarkan penelitian yang dilakukan mengenai pemberian kolostrum pada bayi di Praktik Mandiri Bidan Wilayah Pakansari Kecamatan Cibinong Kabupaten Bogor tahun 2021, hasil penelitian menunjukan bahwa sebagian besar ibu nifas tidak memberikan kolostrum pada bayinya, yaitu sebesar $(53,1 \%)$, sedangkan yang memberikan kolostrum sebesar $(46,9 \%)$. Dari beberapa karakteristik yang didapat, responden yang tidak memberikan kolostrum ialah responden yang memiliki rentan usia 15-20 tahun dengan berbagai alasan yang ada, diantaranya mereka masih dalam usia remaja yang berada dalam fase pembentukan citra tubuh dan identitas seksual, perubahan yang terjadi pada dirinya secara cepat membuat mereka menolak perubahan tersebut, termasuk perubahan untuk menyusui.

Sedangkan, jika dilihat dari faktor pendidikan, responden dengan pendidikan SD memiliki persentase tertinggi dalam hal tidak memberikan kolostrum. Meskipun tidak bisa disimpulkan secara pasti bahwa pendidikan terakhir ibu ialah penghambat mendapatkan pengetahuan, tetapi inilah salah satu faktor yang terjadi di masyarakat. Pendidikan ibu bisa mencerminkan sejauh mana ibu akan memahami manfaat dari pemberian kolostrum ataupun menyusui, maka faktor ini menjadi salah satu faktor penting pula dalam pemberian kolostrum dan menyusui.

Berdasarkan penelitian yang dilakukan oleh Neni Ekowati Januariana dan Marnaini Malaila (2021) menunjukan ada $18(72 \%)$ responden yang memberikan kolostrum kepada bayinya melalui proses IMD (Inisiasi Menyusu Dini). Ada beberapa faktor yang membuat responden memberikan kolostrumnya pada penelitian tersebut, diantaranya pendidikan, pengetahuan, sumber informasi, umur, dan dukungan keluarga. Maka dapat disimpulkan, bahwa penelitian yang dilakukan sesuai dengan penelitian yang dilakukan oleh Neni Ekowati Januariana dan Marnaini Malaila.

Penelitian yang dilakukan sesuai dengan teori yang ada, bahwa kolostrum adalah susu pertama yang keluar dalam bentuk cairan kekuningan yang lebih kental dari ASI matur. Kolostrum diproduksi pada masa kehamilan sampai setelah kelahiran dan akan digantikan oleh ASI transisi dalam dua sampai tiga hari setelah kelahiran bayi (Sutanto, 2018). Kandungan yang ada didalamnya diantaranya protein $8,5 \%$, lemak $2,5 \%$, karbohidrat $3,5 \%$, garam dan mineral $0,4 \%$ air $85,1 \%$, antibodi serta kandungan imonoglobulin lebih tinggi jika dibandingkan dengan ASI matur. Kolostrum ialah nutrisi penting yang wajib diberikan kepada bayi baru lahir.

Wahyuni, dan Sunesni 2018 juga menyatakan bahwa kolostrum dapat memberikan perlindungan ekstra terhadap kuman yang menyerang saluran cerna pada bayi. Sejumlah penelitian lain juga menyatakan bahwa ASI melindungi bayi dari penyakit diare, otitis media, infeksi saluran pernafasan akut bagian bawah, infeksi telinga, batuk, pilek dan penyakit alergi (Mardalena, 2017).

ASI kaya akan antibodi (kolostrum) berguna untuk daya tahan tubuh. Kandungan ASI selama enam bulan pertama menjadi gizi utama dan sesuai bagi bayi yang dapat bermanfaat untuk 4 mematikan kuman dalam jumlah tinggi. Maka pemberian ASI eksklusif yang diawali dengan pemberian kolostrum dapat mengurangi risiko kematian pada bayi (Kemenkes RI, 2019).

Faktor-faktor yang memengaruhi pemberian kolostrum pada ibu nifas dipengaruhi oleh berbagai faktor, baik dari faktor ibu sendiri maupun faktor dari luar. Faktor ibu seperti tingkat pengetahuan, kondisi kesehatan, sikap, paritas, dan persepsi ibu sedangkan faktor dari luar berupa dukungan orang terdekat, petugas kesehatan dan budaya dilingkungan tempat tinggal ibu. Adapun faktor-faktor yang menghambat pemberian kolostrum (ASI) dipengaruhi kurangnya pengetahuan ibu terhadap keunggulan kolostrum (ASI) dan fisiologi laktasi, kurangnya persiapan fisik dan mental ibu, kurangnya dukungan keluarga dan kurangnya dukungan lingkungan (Maryunani, 2012).

Beberapa pendapat mengatakan bahwa yang menghambat ibu menyusui dalam memberikan kolostrum dengan segera, diantaranya takut bayi kedinginan, ibu terlalu Lelah untuk segera menyusui bayinya, kolostrum tidak keluar atau jumlah kolostrum tidak memadai, dan juga beberapa pendapat dan penelitian mengatakan bahwa pemberian kolostrum dapat dipengaruhi oleh tingkat pengetahuan ibu (Farida, L. Marni, dalam Jumriati, 2017).

Dampak bayi yang tidak diberikan kolostrum menjadi mudah terkena alergi atau infeksi akibat kekurangan asupan zat kekebalan yang sebenarnya banyak terkandung pada kolostrum. Selain itu bayi juga mudah tertular berbagai penyakit akibat kekurangan vitamin dan protein. Resiko jangka panjang bagi bayi yakni lebih rentan terserang diare, leukimia atau diabetes (Riskesdas, 2018)

Salah satu upaya untuk meningkatkan keberhasilan pemberian kolostrum adalah melalui pelaksanaan Inisiasi Menyusu Dini (IMD) oleh bayi baru lahir pada ibunya. IMD adalah bayi mulai menyusu sendiri segera setelah lahir, dimana bayi dibiarkan mencari puting susu ibunya sendiri tanpa bantuan siapa pun untuk mencapai puting ibu (Khoniasari (2015).

Tenaga kesehatan khususnya bidan memiliki peran penting dalam menolong persalinan. Pemberian kolostrum dapat dilakukan melalui pelaksanaan inisiasi menyusu dini. Oleh karena itu, tenaga kesehatan dalam menolong persalinan harus lebih aktif dalam pelaksanaan inisiasi menyusu dini untuk memastikan bayi baru lahir segera mendapatkan kolostrum yang sangat penting bagi pertumbuhan dan perkembangannya.

\section{Hubungan Dukungan Keluarga Dengan Pemberian Kolostrum Pada Bayi}

Berdasarkan penelitian yang dilakukan di Praktik Mandiri Bidan Wilayah Pakansari Kecamatan Cibinong Kabupaten Bogor tahun 2021, didapatkan hasil bahwa sebagian ibu nifas tidak didukung keluarga untuk memberikan kolostrum kepada bayinya, yaitu sebesar $(53,1 \%)$. Dan sebagian besar ibu nifas tidak memberikan kolostrum kepada bayinya, dengan jumlah sebesar $(53,1 \%)$. Sedangkan, ibu nifas yang mendapatkan dukungan keluarga untuk memberikan kolostrum serta memberikannya hanya sebesar $(46,9 \%)$.

Hasil analisis hubungan dukungan keluarga dengan pemberian kolostrum pada bayi di Praktik Mandiri Bidan Kelurahan Pakansari Kecamatan Cibinong Kabupaten Bogor 
tahun 2021, hasil uji statistik menggunakan Chi-Square didapatkan $p$-value 0,000 yang artinya $p$-value $<0,05$. Maka, dapat dikatakan Ho ditolak dan Ha gagal ditolak, yang artinya ada hubungan yang bermakna anatar dukungan keluarga dengan pemberian kolostrum pada bayi di Praktik Mandiri Bidan Wilayah Kelurahan Pakansari Kecamatan Cibinong Kabupaten Bogor tahun 2021.

Dalam hal ini, peneliti berpendapat bahwa dukungan keluarga yang diberikan kepada ibu nifas dalam memberikan kolostrum amatlah sangat penting guna tercapainya pemberian kolotrum kepada bayi. Ibu nifas memiliki emosional yang belum stabil, maka dari itu peran keluarga diperlukan untuk menstabilkan emosinya, dan membantu produksi hormon prolaktin lebih cepat, sehingga ibu dapat memberikan kolostrum sebagai tahap awal tercapainya ASI eksklusif.

Berdasarkan penelitian yang dilakukan oleh Kristy Mellya Putri (2018), menyatakan bahwa peran keluarga dalam pemberian kolostrum sangatlah penting. Dengan perasaan ibu yang merasa tenang dan nyaman, maka hormon menyusui yang diproduksi oleh ibu akan lebih cepat, dan dapat membenatu cepat terlaksananya pemberian kolostrum. Bagi responden yang tidak didukung oleh keluarga dalam memberikan kolostrum memiliki peluang lebih besar untuk tidak memberikan kolostrum kepada bayinya. Seperti hasil yang didapatkan, terdapat $20(47,6 \%)$ responden tidak memberikan kolostrum karena dukungan keluarga yang tidak baik. Dan bagi responden yang memiliki dukungan keluarga yang baik, terdapat $17(40,5 \%)$ responden yang memberikan kolostrum, dan $5(11,9 \%)$ responden yang tidak memberikan kolostrum.

Hal tersebut sesuai dengan penelitian yang dilakukan oleh Putri Kinasih (2017), didapatkan hasil analisis hubungan antara dukungan keluarga dengan pemberian kolostrum terdapat $56(96,6 \%)$ responden yang memiliki dukungan kurang baik dan tidak memberikan kolostrum kepada bayinya, serta terdapat 45 $(77,6 \%)$ responden yang memiliki dukungan keluarga kurang baik dan memberikan kolostrum pada bayinya. Serta, terdapat 13 $(22,4 \%)$ responden yang dukungan keluarganya baik dan memberikan kolostrum, serta terdapat $2(3,4 \%)$ responden yang memiliki dukungan baik tetapi tidak memberikan kolostrum.

Hal ini sejalan dengan teori yang dijelaskan oleh Roesli (2008), bahwa dukungan keluarga merupakan faktor eksternal yang berperan sangat penting dalam keberhasilan ASI eksklusif, yang mana dimulai dari tahap pemberian kolostrum.

Faktor-faktor yang memengaruhi pemberian kolostrum pada ibu nifas dipengaruhi oleh berbagai faktor, baik dari faktor ibu sendiri maupun faktor dari luar. Faktor ibu seperti tingkat pengetahuan, kondisi kesehatan, sikap, paritas, dan persepsi ibu sedangkan faktor dari luar berupa dukungan orang terdekat khususnya keluarga, petugas kesehatan dan budaya dilingkungan tempat tinggal ibu. Adapun faktor-faktor yang menghambat pemberian kolostrum (ASI) dipengaruhi kurangnya pengetahuan ibu terhadap keunggulan kolostrum (ASI) dan fisiologi laktasi, kurangnya persiapan fisik dan mental ibu, kurangnya dukungan keluarga dan kurangnya dukungan lingkungan (Maryunani, 2012).

Beberapa pendapat mengatakan bahwa yang menghambat ibu menyusui dalam memberikan kolostrum dengan segera, diantaranya takut bayi kedinginan, ibu terlalu Lelah untuk segera menyusui bayinya, kolostrum tidak keluar atau jumlah kolostrum tidak memadai, dan juga beberapa pendapat dan penelitian mengatakan bahwa pemberian kolostrum dapat dipengaruhi oleh tingkat pengetahuan ibu (Farida, L. Marni, dalam Jumriati, 2017).

Manfaat kolostrum bagi bayi yaitu sebagai antibodi untuk melindungi bayi dari penyakit, membersihkan mekonium dari usus bayi yang baru lahir dan mempersiapkan saluran pencernaan bayi yang akan datang. Kolostrum juga lebih banyak mengandung antibodi dibandingkan dengan ASI yang matur, sehingga dapat memberikan perlindungan bagi bayi sampai usia 6 bulan. Dampak bayi yang tidak diberikan kolostrum menjadi mudah terkena alergi atau infeksi akibat kekurangan asupan zat kekebalan yang sebenarnya banyak terkandung pada kolostrum. Selain itu bayi juga mudah tertular berbagai penyakit akibat kekurangan vitamin dan protein. Resiko jangka panjang bagi bayi yakni lebih rentan terserang diare, leukimia atau diabetes (Riskesdas, 2018)

Tenaga kesehatan yang dapat menjalankan perannya dengan keberhasilan pemberian kolostrum pada bayi baru lahir, khususnya bidan yang menolong persalinan. Petugas kesehatan setelah selesai menolong persalinan dapat memberikan penjelasan tentang pentingnya ibu bayi untuk segera memberikan kolostrum.

Salah satu upaya untuk meningkatkan keberhasilan pemberian kolostrum adalah melalui pelaksanaan Inisiasi Menyusu Dini (IMD) oleh bayi baru lahir pada ibunya. IMD adalah bayi mulai menyusu sendiri segera setelah lahir, dimana bayi dibiarkan mencari puting susu ibunya sendiri tanpa bantuan siapa pun untuk mencapai puting ibu (Khoniasari 2015).

Tenaga kesehatan khususnya bidan memiliki peran penting dalam menolong persalinan. Pemberian kolostrum dapat dilakukan melalui pelaksanaan inisiasi menyusu dini. Oleh karena itu, tenaga kesehatan dalam menolong persalinan harus lebih aktif dalam pelaksanaan inisiasi menyusu dini untuk memastikan bayi baru lahir segera mendapatkan kolostrum yang sangat penting bagi pertumbuhan dan perkembangannya

\section{SIMPULAN}

Berdasarkan hasil penelitian dan pembahasan tentang dukungan keluarga dengan pemberian kolostrum pada bayi di Praktik Mandiri Bidan wilayah Kelurahan Pakansari Kecamatan Cibinong Kabupaten Bogor yang dilakukan peneliti, maka peneliti menyimpulkan dukungan keluarga memiliki peran penting dalam pemberian kolostrum pada bayi dibuktikan dengan uji statistik Chi-Square didapatkan $p$-value $=0,000(p$-value $<0,05)$

\section{UCAPAN TERIMA KASIH}

Penulis mengucapkan terima kasih pada seluruh pihak yang terlibat dalam penelitian ini.

\section{DAFTAR PUSTAKA}

1. Ambarwati. Asuhan Kebidanan Nifas. Yogyakarta: Mitra Cendikia; 2008.

2. Ayuni Dini Qurrata. Buku ajar; asuhan keperawatan pada pasien post operasi katarak. Padang: Pustaka Galeri Mandiri; 2020.

3. Dahlia Iis . Hubungan Dukungan Keluarga Terhadap Status Pemberian Kolostrum Pada Bayi Di Wilayah Kerja Puskesmas Pisangan Kecamatan Ciputat [Skripsi]. Jakarta: 
Fakultas Kedokteran Dan Ilmu Kesehatan Universitas Islam Negeri Syarif Hidayatullah Tahun 2016. Oct 2020

4. Dinas Kesehatan Jawa Barat. Profil Kesehatan Dinas Kesehatan Jawa Barat Tahun 2017. Bandung: Dinas Kesehatan Jawa Barat [Online]. 2017 [Cited 2020 Oct 6]; Available from URL: www.dinkes.jabarprov.go.id

5. Dinas Kesehatan Kabupaten Bogor. Profil Kesehatan Kabupaten Bogor. Narasi Lakip 2016. Bogor: Dinas Kesehatan Kabupaten Bogor [Online]. 2016 [Cited 2020 Nov 3]; Available from URL: www.bogorkab.go.id

6. Januariana Neni Ekowati, Marnaini Malaila. Pemberian Kolostrum Pada Bayi Baru Lahir Di Desa Dasan Raja Kecamatan Penanggalan Kota Subulussalam Provinsi Aceh. Jurnal Dunia Gizi, Vol.4 No.1, Juni 2021:21-29. 2021 [Cited 2021 June 30]; Available from URL: www.ejournal.helvetia.ac.id

7. Jumriati. Faktor yang Berhubungan Dengan Pemberian Kolostrum Pada Bayi Baru Lahir di RskdiaPertiwi Makassar Tahun 2016 [Online]. 2017 [cited 2021 Sept 01] Availabele from URL:http//ejurnalkesehatan//pdf..//65

8. Kemenkes RI. Profil Kesehatan Indonesia Tahun 2018. [Online]. 2019. [cited 2021 Sept 01] Availabele from URL:http://www.depkes.go.id

9. Kementrian Kesehatan Republik Indonesia. Profil Kesehatan Indonesia [Online]. 2019 [Cited 2020 Nov 3]; Available from URL: www.pusdatin.kemkes.go.id

10. Khoniasari Aik. Pengaruh Paritas Pengetahuan Ibu Dukungan Keluarga dan Peran Tenaga Kesehatan Terhadap Inisiasi Menyusu Dini di RSUD Salatiga. [Online]. 2015. [cited 2021 Sept 01] Available from URL: https://digilib. uns.ac.id

11. Khosidah Amik. Faktor-Faktor Yang Mempengaruhi Pemberian Kolostrum Pada Bayi Baru Lahir Di Puskesmas Baturaden Kabupaten Banyumas Tahun 2016. Jurnal Ilmu Keperawatan dan Kebidanan, Vol. 9 No.1. 2018 [Cited 2021 August 28]; Available fro URL : www.ejr.stikesmuhkudus.ac.id

12. Kinasih Putri. Pengaruh Dukungan Keluarga Terhadap Pemberian ASI Eksklusif Di Puskesmas Wonosari I Kabupaten Gungung Kidul [Skripsi]. 2017 [Cited 2021 Jul 1]. Available from URL : www.eprints.poltekkesjogja.ac.id

13. Maita Liva, Na'imatu Shalihah. Faktor-Faktor Yang Menyebabkan Pemberian Kolostrum Pada Ibu Nifas Di Ruang Camar I RSUD Arifin Achmad Provinsi Riau. 2015 [Cited 2021 Sept 2021]. Available from URL : www.ejournal.upp.ac.id

14. Mardalena I. Dasar-Dasar Ilmu Gizi Konsep dan Penerapan Pada Asuhan Keperawatan. Yogyakarta: Pustaka Bru Press; 2017

15. Maryunani. Ilmu Kesehatan Anak Dalam Kebidanan. Jakarta: Trans Info Media; 2012

16. Mastiningsih Putu, Yayuk Chrisyanti Agustina. Buku Ajar: Asuhan Kebidanan Pada Ibu Nifas dan Menyusui. Bogor: In Media. 2019

17. Nadirawati. Buku Ajar: Asuhan Keperawatan Keluarga Teori dan Aplikasi Praktik. Bandung: Refika. 2018

18. Notoatmodjo Soekidjo. Metode Penelitian Kesehatan. Jakarta: Rineka Cipta. 2018
19. Nurrizka Rahma Hida. Kesehatan Ibu dan Anak dalam Upaya Kesehatan Masyarakat. Depok: PT Rajagrafindo Persada. 2019

20. Purwaningsih A, Hasanah O, Utomo W. Hubungan Dukungan Keluarga Terhadap Manajemen Laktasi Pada Ibu Bekerja [serial online] 2013 Des [cited 2021 Agst 31]; 9(2): 175-189. Available from:http://ners.fkep.unand.ac.id/index. php/ners/article/view/69/64

21. Putri Mellya Kristy. Hubungan Pengetahuan, Sikap, Dan DUkungan Keluarga Terhadap Pemberian Kolostrum Di RSIA Annisa Kota Jambi. Jurnal Bahan Kesehatan Masyarakat Vo. 2 No. 2. 2018 [Cited 2021 June 29]. Available from URL: www.jurnalpoltekkesjambi.ac.id

22. Riskesdas. Riset Kesehatan Dasar. Kementrian Kesehatan Republik Indonesia. 2018

23. Soetjiningsih, editor. Seri Gizi Klinik ASI Petunjuk Untuk Tenaga Kesehatan. Jakarta: EGC. 2014

24. Sutanto Andina Vita. Asuhan Nifas \& Menyusui. Yogyakarta: Pustaka Baru. 2018

25. UNICEF. Status Anak Dunia 2019 Anak, Pangan, dan Gizi [Online]. 2019 [Cited 2020 Oct 10]; Available from URL: www.unicef.org

26. Wahyuni Novia Uci, Sunesni. Hubungan Pengetahuan Paritas dan Pendidikan Ibu dengan Prilaku Pemberian Kolostrum di Kelurahan Gunung Sarik Wilayah Kerja Puskesmas Belimbing Tahun 2018. [Serial online]. 2018 Okt [cited 2021 Sept 01] 1(1) Available from URL:http://jurnal.mercubaktijaya.ac.i d/index.php/mercusuar/article/view/16

27. World Health Organization. [Online]. 2019 Sept 19 [cited 2020 Okt 27]; Available from URL: www.who.int

28. Zulala Nuli Nuryanti, Sulistiyaningsih, Siti Arifah. Gambaran Pelaksanaan Inisiasi Menyusu Dini di Rumah Sakit 'Aisyiyah Muntilan. Jurnal Kebidanan [Online]. 2018 [Cited 2021 Jan 27], No. 7 Vol. 2 111-119. Available from URL: www.jurnal.unimus.ac.id 